\title{
Microclimatic Factors and Phenology Influences in the Chemical Composition of the Essential Oils from Pittosporum undulatum Vent. Leaves
}

\author{
João Henrique G. Lago,* Oriana A. Fávero and Paulete Romoff \\ Centro de Ciências e Humanidades, Universidade Presbiteriana Mackenzie, \\ 01302-907 São Paulo-SP, Brazil
}

\begin{abstract}
O óleo essencial das folhas de um espécime brasileiro de Pittosporum undulatum Vent. foi analisado através de cromatografia a gás-espectrometria de massas (CG-EM), além de análise por RMN após separação cromatográfica. As folhas de $P$. undulatum foram coletadas durante um ano (Janeiro, Março, Maio, Julho, Setembro e Novembro de 2004) e os óleos essenciais obtidos foram submetidos à análise por CG e CG/EM. O óleo mostrou-se composto por hidrocarbonetos monoterpênicos e sesquiterpênicos, sendo o (+)-limoneno o constituinte principal. Através dos resultados obtidos por essa análise, observou-se uma variação significativa na proporção relativa de (+)-limoneno em cada uma das coletas realizadas, a qual poderia estar correlacionada a parâmetros microclimáticos (temperatura e índice pluviométrico) além de fenologia da espécie estudada.
\end{abstract}

The essential oil from leaves of a Brazilian specimen of Pittosporum undulatum Vent. was analyzed by means of gas chromatography-mass spectrometry (GC-MS) and NMR analysis after chromatographic separation. The leaves of $P$. undulatum were collected during one year (January, March, May, July, September and November, 2004) and the obtained essential oils were analyzed. The oil is rich in hydrocarbon monoterpenes and sesquiterpenes, being (+)limonene the main constituent. It was observed a significant variation on the relative amount of (+)-limonene in these collections, which could be associated to microclimatic parameters (temperature and pluviometric index) despite of phenology of the studied species.

Keywords: Pittosporum undulatum, essential oil, chemical variability

\section{Introduction}

Pittosporum undulatum (Pittosporaceae), named "pauincenso" in Brazil because its leaves and fruits present a characteristic smell, is a tree of $12 \mathrm{~m}$ in its natural habitat but usually smaller in cultivation (7-10 m). Small, white, fragrant flowers occur in terminal clusters in spring and early summer and are followed by orange-tan berries 1 $\mathrm{cm}$ in diameter in autumn, which persist for several months. This species has been found as a wild plant in tropical forest from Africa, Asia and New Zealand and have been also planted as ornamental specie in other tropical regions of the world such as Brazilian cities, for example São Paulo. ${ }^{1,2}$

The chemical composition of fruits and leaves of $P$. undulatum have been extensively studied and several terpenoid derivatives were found, mainly triterpenoid sapogenins. ${ }^{3-5}$

*e-mail: joaolago@iq.usp.br
The essential oils from several species of Pittosporum have previously been described. The oil from leaves of $P$. senacia collected in Madagascar was composed by $20.4 \%$ of monoterpenes, $31.7 \%$ of sesquiterpene hydrocarbons and $37.8 \%$ of sesquiterpene alcohols being the major compounds $\delta$-cadinene (11.3\%), $\alpha$-muurolol (15.9\%) and $\alpha$-cadinol (19.0\%). ${ }^{6}$ From leaves of $P$. balfourii, collected in Island of Rodrigues, east of Madagascar, was obtained an essential oil composed by $86.2 \%$ of monoterpenes and $4.9 \%$ of sesquiterpenes, and the major component was identified as myrcene $(47.5 \%))^{7}$ In the essential oil from leaves of $P$. viridiflorum, the occurrence of monoterpenes, hydrocarbon sesquiterpenes and oxygenated sesquiterpenes were reported being $\delta$-cadinene $(10.6 \%)$ and $\alpha$-cadinol (18.3\%) the main constituents. ${ }^{8}$ Recently, an extensive study with essential oils from several species of Pittosporum collected on New Zealand have been described. ${ }^{9}$ The oils from $P$. crassifolium, P. fairchildii, $P$. tenuifolium and $P$. umhellatum was constituted mainly by sesquiterpenes and monoterpenes in low abundance. Other 
species such as $P$. anomalum, $P$. eugenioides and $P$. dallii were also studied and their essential oils are rich in sesquiterpene alcohols besides esters such as octyl and phytyl acetate. ${ }^{9}$

The essential oil from leaves of $P$. undulatum has been subject of one published research in which the plant material was collected in San Miguel Island (Azores). This report describes that 17 compounds were identified and the relative amount of each class of compounds have been described. Monoterpenes (1.6\%), hydrocarbon sesquiterpenes (61.5\%), sesquiterpene alcohols $(16.5 \%)$, diterpene $(10.7 \%)$ and alkanes $(6.5 \%)$ were found, being the main constituents the sesquiterpenes calamenene (41.4\%), farnesol (10.9\%), spathulenol (5.6\%) and $\beta$-selinene (5.2\%) and the diterpene $(8 \beta, 13 \beta)$-kaur-16-ene $(10.7 \%) .{ }^{10}$

In continuation with our studies on essential oils from aromatic Brazilian species, the present investigation reports the chemical composition of the essentials from leaves of P. undulatum from Brazil, and compares the difference in the oil content and composition of other Pittosporum species. Despite of the chemical composition of essential oil from $P$. undulatum had been described previously, the effect of the harvesting period in the oil composition had not been reported in the literature.

Effects of environmental factors on the variation on the chemical composition of essential oils were observed in several species such as Virola surinamensis, ${ }^{11}$ Santolina rosmarinifolia ${ }^{12}$ and Helichrysum italicum..$^{13}$ Therefore, we describe here the analysis of the relative percentage of the leaves oils components of this species obtained in six different periods of one year (January, March, May, July, September and November) and a possible relationship with the microclimatic conditions and phenological state of the studied species.

\section{Experimental}

\section{General experimental procedures}

NMR (Bruker DPX-300): ${ }^{1} \mathrm{H}(300 \mathrm{MHz})$ and ${ }^{13} \mathrm{C}(75$ $\mathrm{MHz}$ ) in $\mathrm{CDCl}_{3}$ (Sigma-Aldrich) and TMS as internal standard; LREIMS were obtained at $70 \mathrm{eV}$ (INCOS 50 Finnigan-Mat-quadrupole); optical rotation was measured in EtOH in a digital polarimeter JASCO DIP-370 (Na Filter, $\lambda=588 \mathrm{~nm}$ ); column chromatography: silica gel 60 (Merck, 60-200 $\mu \mathrm{m}$ ).

\section{Plant material}

The leaves of Pittosporum undulatum Vent. (Pittosporaceae) were collected in the Universidade
Presbiteriana Mackenzie Campus, São Paulo, SP, on January, March, May, July, September and November, $15^{\text {th }}$, 2004, in four times during a day (8 a.m., 12 a.m., 4 p.m., 8 p.m.). The leaves were harvested before (January, March, May and July), during (September) and after (November) the flowering stage. The specie was identified by Prof. Dr. Lúcia Rossi from Instituto de Botânica/SP and a voucher specimen was deposited at the Herbarium of the Prefeitura Municipal de São Paulo (PMSP) under code number 8767.

\section{Essential oil distillation}

The fresh leaves were hydro-distillated for $4 \mathrm{~h}$ in a Clevenger type apparatus. The essential oils were separated from water using $\mathrm{CH}_{2} \mathrm{Cl}_{2}$ as solvent, dried over anhydrous $\mathrm{Na}_{2} \mathrm{SO}_{4}$ and stored at $4{ }^{\circ} \mathrm{C}$ in the dark. For chromatographic separation of the oil components, the leaves were collected on July 15 ${ }^{\text {th }}, 2004$ (500 g) and submitted to the same extraction procedure described above, to give $120 \mathrm{mg}$ of crude essential oil (yield $0.02 \%$ ).

\section{Microclimatic factors}

The registered values of temperature and relative humidity have been measured in situ with a digital Pocket Weather Meter Kestrel 3000 (Nielsen-Kellerman - USA). Precipitation values have been registered using a pluviometer made in our laboratory (values in millimeters) from $12^{\text {th }}$ to $18^{\text {th }}$ day in each collection.

\section{Gas chromatography analysis (GC)}

The crude essential oils were analyzed by GC with a Hewlett-Packard 5980 Series II system using an HP-5 column $(30 \mathrm{~m} \times 0.32 \mathrm{~mm}$ internal diameter, with $0.25 \mu \mathrm{m}$ film thickness) and helium as carrier gas $\left(1 \mathrm{~mL} \mathrm{~min}^{-1}\right)$. The oven temperature was kept at $60^{\circ} \mathrm{C}$ and programmed to $280^{\circ} \mathrm{C}$ at a rate of $3^{\circ} \mathrm{C} \mathrm{min}^{-1}$ and kept constant at $280{ }^{\circ} \mathrm{C}$ for $10 \mathrm{~min}$. The injector temperature was at $220{ }^{\circ} \mathrm{C}$ and detector (FID) at $280{ }^{\circ} \mathrm{C}$. The percentage compositions were obtained from electronic integration measurements using flame ionization detector (FID). A serie of linear nalkanes was used as reference points in the calculation of relative Kovats indices (KI).

Gas Chromatography - Mass Spectrometry analysis (GC-MS)

GC-MS analysis was carried out in a Shimadzu GC17A chromatograph interfaced with a MS-QP-5050A mass 
spectrometer. Helium was used as the carried gas. The MS operating conditions were: ionization voltage $70 \mathrm{eV}$, ion source $230{ }^{\circ} \mathrm{C}$. The GC analysis was done with a DB5 column $(30 \mathrm{~m} \times 0.25 \mathrm{~mm}$ internal diameter, with $0.25 \mu \mathrm{m}$ film thickness) and the operating conditions were identical with those of the GC analysis.

Retention indices for all compounds were determined according to the Kovats method relative to the linear nalkanes series $\left(\mathrm{C}_{8}\right.$ to $\left.\mathrm{C}_{20}\right)$. The identification of the compounds was done by comparison of Kovats indices and by matching their fragmentation patterns in mass spectra with those of standard compounds and published mass spectra data ${ }^{14}$ along with mass spectra of authentic compounds.

\section{Chiral phase-Gas Chromatography analysis (GC)}

The enantiomeric excess of limonene was determined by GC in a Shimadzu GC17A system using a Varian $\mathrm{W}_{\text {cot }}$ fused silica coated with CP Chirasil-dex CB $(25 \mathrm{~m} \times 0.25$ $\mathrm{mm}$ internal diameter, with $0.25 \mu \mathrm{m}$ film thickness) as stationary phase and helium as carried gas $\left(1 \mathrm{~mL} \mathrm{~min}^{-1}\right)$. The oven temperature was kept at $60^{\circ} \mathrm{C}$ and programmed to $280{ }^{\circ} \mathrm{C}$ at a rate of $5{ }^{\circ} \mathrm{C} \mathrm{min}^{-1}$ and kept constant at $280{ }^{\circ} \mathrm{C}$ for $5 \mathrm{~min}$. The injector temperature was at $220{ }^{\circ} \mathrm{C}$ and detector (FID) at $280{ }^{\circ} \mathrm{C}$.

\section{Essential oil separation}

Part of the crude essential oil $(80 \mathrm{mg}$ ) was submitted to separation in a silica gel coated with $\mathrm{AgNO}_{3}$ column, ${ }^{15}$ using pentane, a mixture of pentane: $\mathrm{CH}_{2} \mathrm{Cl}_{2}(1: 1), \mathrm{CH}_{2} \mathrm{Cl}_{2}$ and $\mathrm{CH}_{2} \mathrm{Cl}_{2}$ :acetone $1: 1$ as eluents ${ }^{16,17}$ giving 25 fractions which were individually analyzed by gas chromatography. GC chromatogram of fractions 3-7 $(20 \mathrm{mg})$ indicated that these were composed by one major component $(99 \%)$ which was identified as (+)-limonene by ${ }^{1} \mathrm{H}$ and ${ }^{13} \mathrm{C} \mathrm{NMR}$ spectral analysis, specific optical rotation and comparison with literature data. ${ }^{18,19}$ The enantiomeric excess was determined by chiral GC analysis which indicated the predominance of (+)-limonene (99\% e.e.).

(+)-limonene. Oil; $[\alpha]_{\mathrm{D}}{ }^{25}=+44.0^{\circ}\left(c\right.$ 5.0, EtOH); ${ }^{1} \mathrm{H} \mathrm{NMR}$ $\left(\mathrm{CDCl}_{3}, \delta, 300 \mathrm{MHz}\right): 5.39$ (m, 1H, H-2), 4.70 (s, 2H, H9), 2.2-1.4 (m, H-3, H-4, H-5 and H-6), 1.73 (s, 3H, H-7), 1.64 (s, 3H, H-10). $\left.{ }^{13} \mathrm{C} \mathrm{NMR} \mathrm{(CDCl}, \delta, 75 \mathrm{MHz}\right): 149.6$ (s, C-8), 133.1 (s, C-1), 120.8 (d, C-2), 108.4 (t, C-9), 41.2 (d, C-4), 30.8 (t, C-6), 30.6 (d, C-3), 28.0 (t, C-5), 23.7 (q, C-7), 20.5 (t, C-10). LREIMS (70 eV) $\mathrm{m} / \mathrm{z}$ (int. rel.) $136[\mathrm{M}]^{+}$(14), 121 (16), 107 (17), 93 (60), 79 (33), 68 (100), 53 (29), 39 (40).

\section{Results and Discussion}

The crude essential oils from leaves of Pittosporum undulatum were analyzed by GC (DB-5 capillary column) and GC-MS associated to determination of the Kovats indexes. The oil contained ten identified components, corresponding to monoterpenes $(\beta$-pinene, $\beta$-myrcene, limonene, $\delta$-elemene) and sesquiterpenes $(\alpha$-copaene, $\beta$-elemene, $\beta$-caryophyllene, aromadendrene, bicyclogermacrene, $\delta$-cadinene), being limonene the main constituent. Literature data indicated that $(+)$-limonene showed insecticidal activity against Rhyzopertha dominica (F.), lesser grain borer, and Tribolium castaneum (Herbst), red flour beetle, which are important pests of stored grain. ${ }^{19}$

Additionally, the crude oil was fractionated by $\mathrm{SiO}_{2} /$ $\mathrm{AgNO}_{3}$ column followed by $\mathrm{GC}$ analysis, which indicated that fractions 3-7 were composed by a pure component $(99.7 \%)$. These fractions were pooled together and submitted to chiral gas chromatography analysis, measurement of specific optical rotation, LREIMS and ${ }^{1} \mathrm{H}$ and ${ }^{13} \mathrm{C}$ NMR spectrometry to confirm the identity of the main component as (+)-limonene, in comparison with literature data. ${ }^{18,19}$

To verify the accumulation of this monoterpene as major component, the crude oils of $P$. undulatum were obtained from leaves collected on the $15^{\text {th }}$ day in January, March, May, July, September and November, 2004 (four samples in each collection) and submitted to GC and GC/ MS analysis. The medium values of components in the essential oils obtained from each collection, in the six months of analysis, corresponding to monoterpenes $(68 \pm 10-83.9 \pm 0.6 \%)$ and sesquiterpenes $(7 \pm 1-11 \pm 1 \%)$, as showed in Table 1. The yields of the essential oils appear in Table 2, along with registered precipitation, relative humidity, temperature values and phenology of the analyzed specimen.

We have detected quantitative but not qualitative variations on the yields and chemical constituents of the essential oil during the period of study. The yields of the essential oils were constant when the leaves were collected in the specimen sterile period $(0.02 \%)$, and increase in the flowering and fruiting stages (0.05- $0.06 \%$, respectively).

During the sterile period (January, March, May and July) the relative level of $(+)$-limonene, was not constant $(67 \pm 10$ to $80.8 \pm 0.4 \%$ ), which could be related to microclimatic factors such as temperature, air relative humidity and precipitation. ${ }^{19}$ As showed in Table 1, in March and July the relative proportion of (+)-limonene was lower $(67 \pm 10$ and $69 \pm 3 \%$, respectively) in comparison with other collection periods. In these months the precipitation values 
Table 1. Compounds identified and percentage composition from the volatile oil of the leaves of Pittosporum undulatum

\begin{tabular}{|c|c|c|c|c|c|c|c|}
\hline compounds $^{\mathrm{a}}$ & $\mathrm{KI}^{\mathrm{b}}$ & January & March & May & July & September & November \\
\hline$\beta$-pinene & 980 & $1.9 \pm 0.2$ & $0.8 \pm 0.2$ & $1.7 \pm 0.3$ & $2.8 \pm 0.4$ & $1.3 \pm 0.2$ & $1.8 \pm 0.3$ \\
\hline$\beta$-myrcene & 991 & $1.19 \pm 0.06$ & $0.67 \pm 0.08$ & $0.3 \pm 0.3$ & $0.86 \pm 0.01$ & $0.7 \pm 0.1$ & $0.88 \pm 0.02$ \\
\hline$(+)$-limonene & 1031 & $80.8 \pm 0.4$ & $67 \pm 10$ & $76 \pm 4$ & $69 \pm 3$ & $78 \pm 6$ & $76 \pm 6$ \\
\hline$\delta$-elemene & 1339 & $0.08 \pm 0.01$ & $0.12 \pm 0.02$ & - & $0.09 \pm 0.01$ & $0.16 \pm 0.02$ & $0.16 \pm 0.03$ \\
\hline$\alpha$-copaene & 1376 & $0.41 \pm 0.04$ & $0.56 \pm 0.05$ & $0.35 \pm 0.02$ & $0.39 \pm 0.04$ & $0.7 \pm 0.1$ & $0.77 \pm 0.06$ \\
\hline$\beta$-elemene & 1391 & $0.54 \pm 0.03$ & $1.2 \pm 0.4$ & $0.59 \pm 0.06$ & $0.55 \pm 0.05$ & $0.7 \pm 0.1$ & $0.50 \pm 0.09$ \\
\hline$\beta$-caryophyllene & 1418 & $0.14 \pm 0.01$ & $0.32 \pm 0.04$ & $0.21 \pm 0.06$ & $0.19 \pm 0.01$ & $0.30 \pm 0.07$ & $0.23 \pm 0.02$ \\
\hline aromadendrene & 1439 & $0.33 \pm 0.04$ & $1.3 \pm 0.3$ & $0.24 \pm 0.03$ & $0.36 \pm 0.03$ & $0.39 \pm 0.03$ & $0.36 \pm 0.03$ \\
\hline biclyclogermacrene & 1494 & $5.3 \pm 0.1$ & $6.8 \pm 0.8$ & $6.2 \pm 0.8$ & $5.6 \pm 0.9$ & $4.1 \pm 0.8$ & $6.7 \pm 0.8$ \\
\hline$\gamma$-cadinene & 1513 & $0.15 \pm 0.02$ & $0.53 \pm 0.08$ & $0.4 \pm 0.2$ & $0.33 \pm 0.04$ & $0.47 \pm 0.09$ & $0.40 \pm 0.02$ \\
\hline Monoterpenes & & $83.9 \pm 0.6$ & $68 \pm 10$ & $79 \pm 4$ & $73 \pm 2$ & $80 \pm 6$ & $79 \pm 6$ \\
\hline Sesquiterpenes & & $7.0 \pm 0.1$ & $11 \pm 1$ & $8 \pm 1$ & $8 \pm 1$ & $7 \pm 1$ & $9.1 \pm 0.7$ \\
\hline TOTAL & & $90.9 \pm 0.6$ & $79 \pm 9$ & $87 \pm 4$ & $80 \pm 1$ & $87 \pm 6$ & $88 \pm 6$ \\
\hline
\end{tabular}

arder of elution from the GC column. ${ }^{\mathrm{a}}$ Retention index on DB-5 capillary coated column.

Table 2. Essential oil yield, microclimatic (precipitation, air relative humidity and temperature) and phenological factors registered in the collection periods

\begin{tabular}{|c|c|c|c|c|c|c|}
\hline & January & March & May & July & September & November \\
\hline Essential oil yield /\% & 0.02 & 0.02 & 0.02 & 0.02 & 0.06 & 0.05 \\
\hline Precipitation / mm & 0 & 33 & 8 & 65 & 16 & 39 \\
\hline Air relative humidity $1 \%$ & $64 \pm 5$ & $76 \pm 5$ & $81 \pm 1$ & $72 \pm 9$ & $64 \pm 5$ & $77 \pm 4$ \\
\hline Temperature $/{ }^{\circ} \mathrm{C}$ & $23 \pm 3$ & $21 \pm 2$ & $16.3 \pm 0.8$ & $14 \pm 2$ & $25 \pm 3$ & $24 \pm 2$ \\
\hline Phenological factor & sterile & sterile & sterile & sterile & flowering & fructification \\
\hline
\end{tabular}

were high (33 and $65 \mathrm{~mm}$, respectively) which suggest an influence of this microclimatic factor in the accumulation of (+)-limonene in the crude essential oil. ${ }^{12}$ However, in September and November ( $78 \pm 6$ and $76 \pm 6 \%$, respectively), in the flowering and fructification periods, the relative amount of (+)-limonene was higher than March and July $(67 \pm 10$ and $69 \pm 3 \%$, respectively) despite of the high precipitation index in November $(39 \mathrm{~mm})$. High values of limonene in the essential oil from leaves of Helichrysum italicum in flowering stage were observed previously. ${ }^{13}$ These data suggest that in the flowering and fructification periods the production of more volatile derivatives was intensified, in agreement to literature data. ${ }^{11,12}$

Besides, a relationship between production of more volatile compounds and air relative humidity has been observed..$^{20}$ In the present study we detected a higher production of monoterpenes, mainly (+)-limonene, in a dry season (January) when the air relative humidity was $64 \pm 5 \%$ (sterile period).

Therefore, although precipitation, temperature and relative humidity might be expected to affect the oil chemical composition, it also could be partially depend on the phenological state..$^{22}$

It is important to mention that in the $P$. undulatum leaves oil previously analyzed by Mananjarasoa et al. ${ }^{6}$ was observed a predominance of hydrocarbon sesquiterpenes, being calamenene the main constituent (41.4\%), and a low amount of oxygenated derivatives. In the present work the main constituents were the hydrocarbon monoterpenes, being (+)-limonene the major component. The occurrence of one monoterpene (myrcene $47.5 \%$ ) as the most abundant component has been described previously by Gurib-Fakim and Demarne, ${ }^{7}$ in the essential oil from the leaves of P. balfourii. Therefore, the composition of the essential oil of $P$. undulatum collect in Brazil is quite different from the oils extracted from others Pittosporum species, which should be associated to several environmental factors.

\section{Acknowledgments}

The authors are grateful to MACKPESQUISA for the financial support, Prof. Dr. Lucia Rossi by the identification of the plant material and Edna Kagohara and Dr. André L.M. Porto (IQ-USP) by chiral GC analysis.

\section{Supplementary Information}

Supplementary data are available free of charge at http://jbcs.sbq.org.br, as PDF file. 


\section{References}

1. Pio-Correa, M.; Dicionário de Plantas Úteis do Brasil e das Exóticas Cultivadas, Imprensa Nacional: Rio de Janeiro, 1984, vol. 4.

2. Lorenzi, H.; Árvores Exóticas no Brasil: Madeireiras, Ornamentais e Aromáticas, Instituto Plantarum: Nova Odessa, 2003.

3. Higuchi, R.; Komori, T.; Kawasaki, T.; Lassak, E.; Phytochemistry 1983, 22, 1235.

4. Higuchi, R.; Fujioka, T.; Iwamoto, M.; Komori, T.; Kawasaki, T.; Lassak, E.; Phytochemistry 1983, 22, 2565.

5. Knight, J. O.; White, D. E.; Tetrahedron Lett. 1961, 3, 100.

6. Mananjarasoa, E.; Rakotovao, M.; Ramanoelina, A. R. P.; Andriantsiferana, M. H.; Ravaonindrina, N.; J. Essent. Oil Res. 1998, 10, 459.

7. Gurib-Fakim, A.; Demarne, F. E.; Planta Med. 1994, 60, 584.

8. Ramanandraibe, V.; Rakotovao, M.; Andriamaharavo, R. N.; Bessiere, J. M.; Ravaonindrina, N.; Ramanoelina, A. R. P.; J. Essent. Oil Res. 2000, 12, 650.

9. Weston, R. J.; J. Essent. Oil Res. 2004, 16, 453.

10. Medeiros, J. R.; Campos, L. B.; Mendonça, S. C.; Davin, L. B.; Lewis, N. G.; Phytochemistry 2003, 64, 561.

11. Lopes, N. P.; Kato, M. J.; Andrade, E. H. A.; Maia, J. G. S.; Yoshida, M.; Phytochemistry 1997, 46, 689.

12. Pala-Paúl, J.; Pérez-Alonso, M. J.; Velasco-Negueruela, A.; Pala-Paúl, R.; Sanz, J.; Conejero, F.; Biochem. Syst. Ecol. 2001, $29,663$.
13. Angioni, A.; Barra, A.; Arlorio, M.; Coisson, J. D.; Russo, M. T.; Pirisi, F. M.; Satta, M.; Cabras, P.; J. Agric. Food Chem. 2003, 51, 1030.

14. Adams, R.P.; Identification of Essential Oil Components by Gas Chromatography/Quadrupole Mass Spectroscopy, Allured Publishing Corporation: Carol Stream, Illinois, USA, 2001.

15. Gripta, A. S.; Dev, S.; J. Chromatogr. 1963, 12, 189.

16. Brochini, C. B.; Nuñez, C. V.; Moreira, I. C.; Roque, N. F.; Chaves, M. H.; Martins, D.; Quim. Nova 1999, 1, 37.

17. Lago, J. H. G.; Reis, A. A.; Roque, N. F.; Flavour Frag. J. 2002, 17, 255.

18. Ferreira, M. J. P.; Emerenciano, V. P.; Linia, G. A. R.; Romoff, P.; Macari, P. A. T.; Rodrigues, G. V.; Prog. Nucl. Magn. Reson. Spectrosc. 1998, 33, 153.

19. Prates, H. T.; Santos, J. P; Waquil, J. M.; Fabris, J. D.; Oliveira, A. B.; Foster, J. E.; J. Stored Prod. Res. 1998, 34, 243.

20. Vallat, A.; Gu, H.; Dorn, S.; Phytochemistry 2005, 66, 1540.

21. Mann, J.; Davidson, R. S.; Hobss, J. B.; Banthhorpe, D. V.; Harborne, J. B.; Natural Products: Their Chemistry and Biological Significance, Longman: Harlow, England, 1994.

22. Oliveira, M. J.; Campos, I. F. P.; Oliveira, C. B. A.; Santos, M. R.; Souza, P. S.; Santos, S. C.; Seraphin, J. C.; Ferri, P. H.; Biochem. Syst. Ecol. 2005, 33, 275.

Received: January 3, 2006

Published on the web: September 26, 2006

FAPESP helped in meeting the publication costs of this article. 
Microclimatic Factors and Phenology Influences in the Chemical Composition of the Essential Oils from Pittosporum undulatum Vent. Leaves

João Henrique G. Lago,* Oriana A. Fávero and Paulete Romoff

Centro de Ciências e Humanidades, Universidade Presbiteriana Mackenzie,

01302-907 São Paulo-SP, Brazil

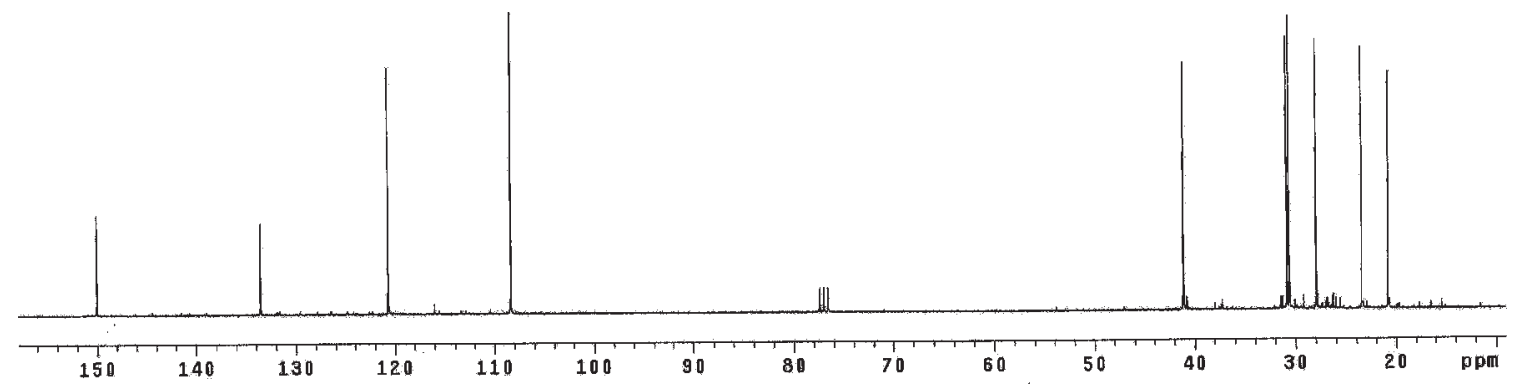

Figure S1. ${ }^{13} \mathrm{C}$ NMR spectrum of (+)-limonene $\left(\delta, \mathrm{CDCl}_{3}, 75 \mathrm{MHz}\right)$.

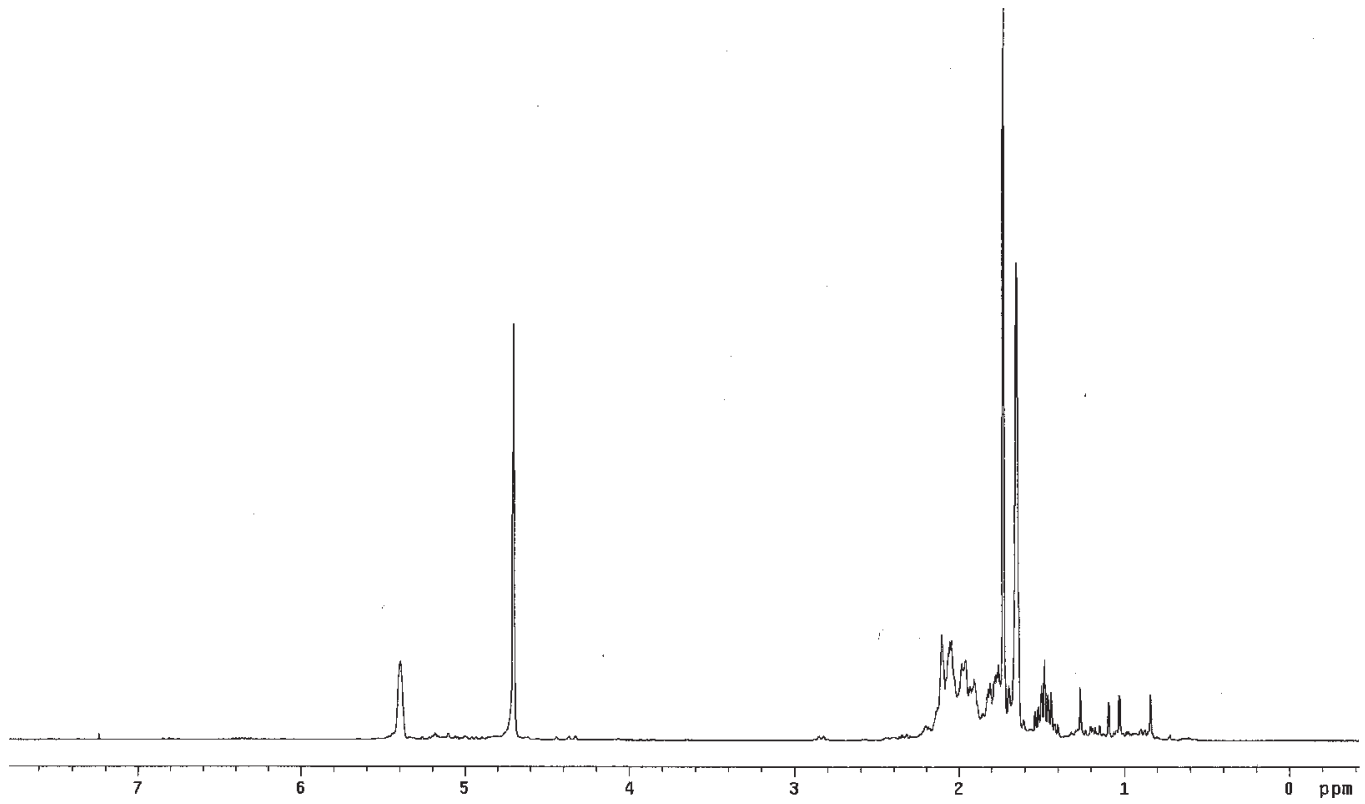

Figure S2. ${ }^{1} \mathrm{H}$ NMR spectrum of (+)-limonene $\left(\delta, \mathrm{CDCl}_{3}, 300 \mathrm{MHz}\right)$.

*e-mail: joaolago@iq.usp.br 


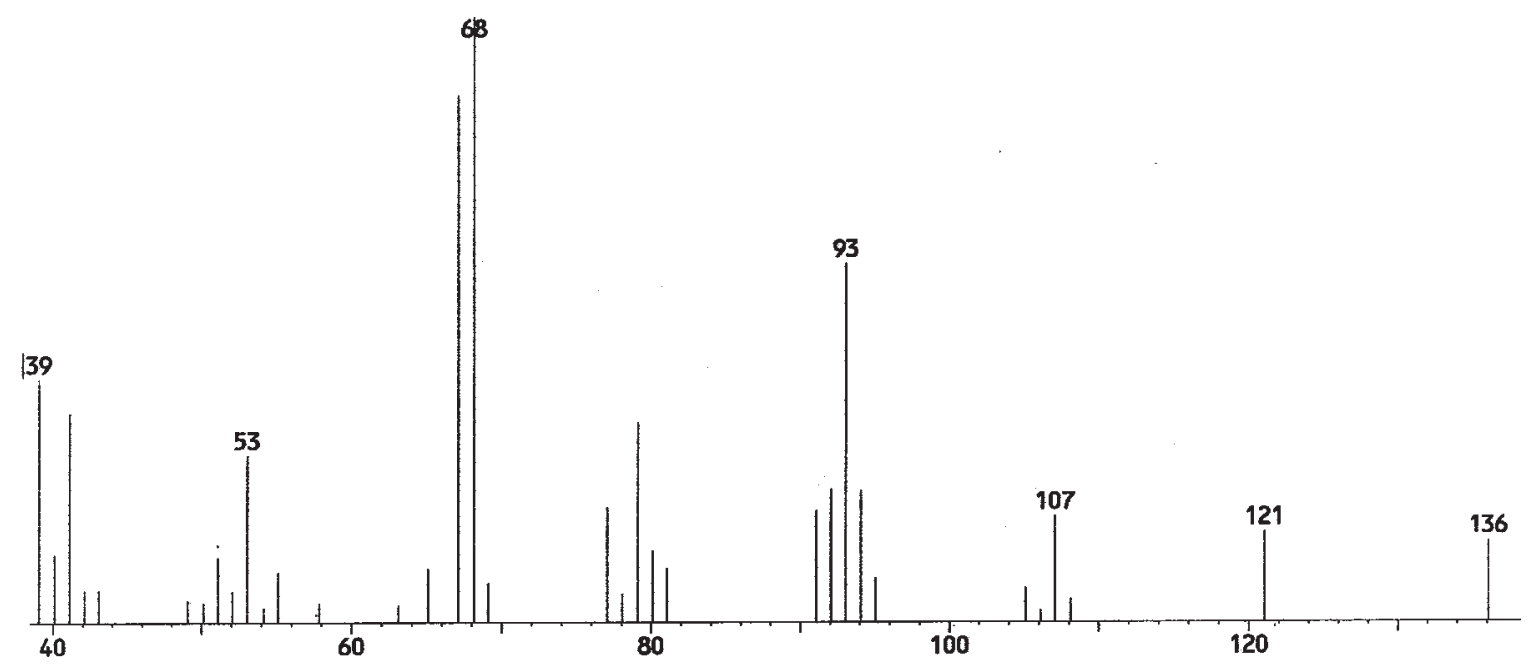

Figure S3. LREIMS spectrum of (+)-limonene $(70 \mathrm{eV})$. 